\title{
LITOGEOQUíMICA DAS ROCHAS METABÁSICAS DA NAPPE DE PASSOS, SW DE MINAS GERAIS: IMPLICAÇÕES TECTÔNICAS Ȧ EVOLUÇÃO DA FAIXA BRASÍLIA MERIDIONAL
}

\author{
C.M.Valeriano ${ }^{1}$, L.S.A.Simões ${ }^{2}$
}

Este trabalho discute as características geoquímicas de 20 amostras de xistos verdes e anfibolitos ortoderivados que ocorrem intercalados na pilha metassedimentar da Nappe de Passos, porção meridional da Faixa Brasília, com ênfase na ambientação tectônica dos protólitos e suas relações com a evolução estratigráfica da nappe. A porção meridional da Faixa Brasília é caracterizada por cavalgamentos epidérmicos e dobramento, com transporte tectônico de pelo menos $150 \mathrm{~km}$ para leste, sobre o bordo sudoeste do Cráton do São Francisco, durante o Neoproterozóico (ca. $600 \mathrm{Ma}$ ), no contexto da Orogênese Brasiliana. Três unidades tectônicas principais são separadas por superficies de empurrão e mostram características litológicas, estruturais, geocronológicas e metamórficas contrastantes (Simões \& Valeriano, 1995; Valeriano, 1992; Simões, 1995): Domínio Autóctone, Domínio Alóctone Externo e Domínio Alóctone Interno. Este último, na região meridional da Faixa Brasília, compreende a Nappe de Passos.

A Nappe de Passos é a unidade tectônica estruturalmente superior, composta por metassedimentos, de idade provavelmente pós-1.8 Ga, que contém lentes delgadas de xistos verdes e anfibolitos ortoderivados, que são objeto deste trabalho. A nappe é caracterizada por um gradiente metamórfico inverso, da fácies xisto verde superior, zona da biotita, à fácies anfibolito superior, no topo. Duas unidades sedimentares são discriminadas: a Unidade Inferior (espessura cerca de $700 \mathrm{~m}$ ) compreende metapelitos com lentes carbonáticas e camadas subordinadas de quartzito. Os quartzitos, em direção ao topo, tornam-se mais espessos e freqüentes, o que sugere uma seqüência de plataforma regressiva, com sedimentação siliciclástica crescente sobre depósitos carbonáticos plataformais; e a Unidade Superior (espessura cerca de $3000 \mathrm{~m}$ ), que se inicia com paragnaisses gradacionais com os xistos micáceos do topo da Unidade Inferior. Esta transição marca o início de condições tectônicas mais instáveis, em que a erosão do embasamento granito-gnáissico e/ou de outras fontes gerou abundantes paragnaisses e xistos feldspáticos. Para o topo, a Unidade Superior exibe metapelitos predominantes com intercalações de paragnaisses e leitos finos de rochas cálcio-silicáticas e gondito. Esta associação de litofácies sugere um ambiente mais francamente marinho. A Unidade Superior contém também intercalações de rochas metabásicas mais freqüentes, em relação à Unidade Inferior.

As rochas metabásicas ocorrem ao longo de toda sucessão sedimentar preservada e exibem a mesma história deformacional e metamórfica dos metassedimentos envolventes, indicando ou extrusão sin-sedimentar, com diques/soleiras, ou apenas diques e soleiras anteriores à inversão tectônica da bacia. Entretanto, variações composicionais sistemáticas em relação à posição estratigráfica favorecem a hipótese de processos extrusivos sin-sedimentares.

\footnotetext{
${ }^{1}$ DGRG, Faculdade de Geologia, Universidade do Estado do Rio de Janeiro.

${ }^{2}$ DPM, Instituto de Geociências e Ciências Exatas, Universidade Estadual Paulista.
} 
A maioria das amostras é de basaltos toleíticos subalcalinos (15 amostras) e andesitos basálticos (2), com $\mathrm{SiO}_{2}$ entre 47 e $52 \%$ em peso. As exceções são 3 traqui-andesitos basálticos, dos quais 2 são levemente alcalinos. Os teores em $\mathrm{MgO}$ são menores que $9 \%$, com correlação positiva com $\mathrm{CaO}$, indicando um controle composicional predominante pelo processo de cristalização fracionada de clinopiroxênio. As tendências composicionais de elementos maiores e traços, incluindo ETR, definem três grupos composicionais: de alto $(>2 \%) \mathrm{TiO}_{2}$ (ATi); baixo $\mathrm{TiO}_{2}$ com ETR fracionado (BTiF) e baixo $\mathrm{TiO}_{2}$ com ETR não fracionado (BTiNF). $\mathrm{O}$ conjunto ATi compreende magmas mais primitivos, com Mg\# entre 25 e 43, e conspícuo enriquecimento em $\mathrm{Nb}, \mathrm{Zr}, \mathrm{Y}$ e Ba. Os padrões de ETR normalizados por condrito são fracionados, com razões $\mathrm{La} / \mathrm{Lu}$ entre 55 e 111. A correlação positiva de $\mathrm{Al}_{2} \mathrm{O}_{3}$ com $\mathrm{CaO}$ indica uma diferenciação magmática envolvendo a cristalização fracionada de plagioclásio e clinopiroxênio. Os grupos BTiF e BTiNF representam magmas relativamente mais primitivos, com Mg\# entre 45 e 61 . As amostras do grupo BTiF são menos fracionadas em ETR ( $\mathrm{La} / \mathrm{Lu}$ entre 25-83), com correlação positiva de $\mathrm{CaO}$ e $\mathrm{Al}_{2} \mathrm{O}_{3}$ com $\mathrm{MgO}$ (cristalização fracionada de plagioclásio+clinopiroxênio). $\mathrm{O}$ grupo BTiNF exibe padrões de ETR achatados $(\mathrm{La} / \mathrm{Lu}$ 10-14). Os teores normalizados deste grupo situam-se abaixo de $9 \mathrm{x}$ condrito, com empobrecimento de ETR leves. Neste conjunto, a correlação negativa de $\mathrm{Al}_{2} \mathrm{O}_{3}$ e $\mathrm{MgO}$ sugere que a cristalização fracionada de plagioclásio não ocorreu durante sua diferenciação magmática.

Diagramas de discriminação tectônica e comparação com amostras de ambientes tectônicos bem caracterizados, identificam os grupos ATi e BTiF como típicos basaltos de platôs continentais ("continental flood basalts" - CFB). Diferentes razões entre elementos incompativeis, especialmente $\mathrm{Nb}, \mathrm{Zr}$ e Y, nestes dois grupos, refletem processos não relacionados à diferenciação magmática para suas origens. As possibilidades incluem fontes mantélicas distintas, misturas de fontes mantélicas distintas e graus variados de contaminação crustal continental. Em contraste, o grupo BTiNF exibe consistente similaridade com basaltos de crista oceânica ("mid-ocean ridge basalts"-MORB) do tipo normal a transicional.

A distribuição das amostras dos três grupos discriminados, ao longo da sucessão estratigráfica, permite tecer importantes inferências sobre a evolução da paleo-bacia sedimentar pós-1.8 Ga: as amostras ATi concentram-se na porção inferior da pilha sedimentar, até os paragnaisses basais da Unidade Superior, porém também ocorrem ao longo de toda a coluna estratigráfica; as amostras BTiF ocorrem apenas na mesma seção inferior; e as amostras BTiNF ocorrem somente na porção superior da coluna.

Tendo como premissa que a amostragem seja representativa, esta distribuição indica que a sedimentação basal (preservada) da nappe de Passos evoluiu associada a processos de distensão continental, com magmatismo básico do tipo CFB, que continuou ao longo de toda coluna sedimentar. Durante a sedimentação da Unidade Superior, em condições marinhas, magmas do tipo MORB foram gerados, indicando distensão e adelgaçamento continental mais severo. Entretanto, a persistência de magmatismo continental neste estágio é uma indicação de que a geração de assoalho oceânico não foi alcançada durante o adelgaçamento litosférico na porção meridional da Faixa Brasilia.

\section{Referências Bibliográficas}

SIMÕES, L.S.A. (1992) Evolução tectonometamórfica da nappe de Passos, sudoeste de Minas Gerais. São Paulo, 149p. (Tese - Doutorado) - Instituto de Geociências, Universidade de São Paulo.

SIMÕES, L.S.A.; VALERIANO, C.M. (1990) Porção meridional da Faixa de Dobramentos Brasilia: estágio atual do conhecimento e problemas de correlação tectono-estratigráfica. In: 
CONGRESSO BRASILEIRO DE GEOLOGIA, 36., Natal, 1990. Anais. Natal, SBG, v. 6, p.2564-2575.

VALERIANO, C.M. (1992) Evolução tectônica da extremidade meridional da Faixa Brasília, região da Represa de Furnas, sudoeste de Minas Gerais. São Paulo, 192p. (Tese - Doutorado) - Instittuto de Geociências, Universidade de São Paulo. 